\title{
Bildung in the Era of Digital Media
}

\author{
Jesper Tække and Michael Paulsen \\ Centre for Internet Research, Aarhus University, Denmark \\ Department of Learning and Philosophy Aalborg University, Denmark
}

\begin{abstract}
We are living in a period when new social structures arise in the communicative space and wake of digital media. This means that we must respond to a changing social world within all social spheres, including economy, work life, love relations and, last but not least, education. The issue we are dealing with in this article is how one should respond educationally to the new media situation. Or more precisely: What should or could Bildung (edification) be within the current environment of new media. It draws on Luhmann (2006), Biesta (2006), Klafki (2014) and Kant (1784), describing what Bildung is, seen from the point of view of the enlightenment tradition, and sets out to discuss and analyse how ideas of Bildung could be used in education today and tomorrow. The paper draws on empirical findings from the Socio Media Education Experiment, a Danish action research project in an upper secondary school from 2011-2014 (Tcekke \& Paulsen 2013a, 2015a, 2016a, 2016b).
\end{abstract}

url:

\section{What is Bildung?}

The concept of Bildung is German and literately means imaging. Like it is said that God created mankind in his own image, the concept addresses the question of what image we are to be formed in: what cultural capital do we want new generations to acquire? Thinkers like Kant, Herder, Humboldt, Hegel and Schleiermacher shaped the concept during the time of the enlightenment (Klafki 2014). Following Luhmann (2006), Bildung is a paradoxical concept, which we see right from the beginning of the time of enlightenment when Kant answered the question: 'what is enlightenment?': "Enlightenment is man's emergence from his self-imposed immaturity. Immaturity is the inability to use one's understanding without guidance from another" (Kant 1784)1. The paradox is that Kant is also of the opinion that the ability to think freely and for oneself is the product of education. He did not only say that: "Man is the only being who needs education" (Kant $1803, \# 1$ ), but also that: "Discipline changes animal nature into human nature" (\#3) and that: "Above all things, obedience is an essential feature in the character of a child, especially of a school boy or girl" (\#80). All in all, the paradox is that on the one hand we have to think for ourselves (Dare to Think for Yourself), while on the other we must be educated, disciplined and learn obedience. We will return to this paradox regarding how students can be educated to become independently thinking beings, to be self-assured, and on the other hand take into consideration others and the common good, providing us with the question of otherness in relation to the concept of Bildung.

Another important element of the concept of Bildung is that it must be brought about with an eye to a future that is better than the present. Again, Kant was a first mover in saying that: "children ought 
to be educated, not for the present, but for a possibly improved condition of man in the future; that is, in a manner which is adapted to the idea of humanity and the whole destiny of man. This principle is of great importance. Parents usually educate their children merely in such a manner that, however bad the world may be, they may adapt themselves to its present conditions" (Kant \#15). And Kant's idea was that this better future is only possible because of better education: "But they ought to give them an education so much better than this, that a better condition of things may thereby be brought about in the future" (ibid.). This is also paradoxical because how can we form a better future by educating students in the present with only present thoughts and methods?

\section{Bildung as a Paradox}

According to Luhmann (2006: 205), the concept Bildung was a societal response to the situation that occurred after the introduction of printed books, when external definitions of what man is or should be were lost. Luhmann proposes the function of the concept as the contingency formula of the function system of education. When we do not know what man is or should be, neither do we know what the education system must achieve. We can ease this embarrassment by finding a concept that, on the one hand, has such scope that it does the embarrassment justice and, on the other hand, has such a normative character that it can provide the education system with guidelines (ibid: 206-207). Luhmann observes Bildung as a paradox with two sides, where the point is not to side with one or the other, but to interpret the function of Bildung as a contingency formula. According to Luhmann, one can also distinguish in a different way between the two sides of Bildung: here, one side opts for a normative form à la canon-based curriculum, whereas the other side opts for a reflective form of Bildung wherein the content of Bildung cannot be settled. Bildung only belongs to the person who can put themselves in the place of another, take the perspective of the other (others will always have a different Bildung, and one can only observe oneself through the eyes of the other). We will return to Bildung as a paradox, trying to use this angle as an analytical method.

\section{A Brief Media History of Bildung}

The prototypical form of Bildung came about with alphabet writing in Ancient Greece under the term of paideia, and in Rome under the term of humanitas. Both concepts were about an autonomous striving for knowledge and insight in a way that was free from business terms and thinking (Larsen 2013). In the dark ages and up until the time of the printing press and the renaissance, reading and writing belonged only to the few, and their knowledge almost only consisted in learning the books that were canonised by the church (in addition to the seven liberal arts). After the invention of the printing press, native languages also became written languages, giving birth to nationalistic (romantic) thinking (Eisenstein 1983) and, ultimately, also to Herder's concept of Bildung. This concept regarded learning about and preserving the special history, culture and language of nations. Even though many famous humanists have shaped the concept, still it has a nationalistic bias. In the wake of the printing press (but also democratic reforms etc.), general (Allgemeine) school systems slowly developed all over Europe, trying to provide young people with (Allgemein)Bildung. This was a top-down managed educational system with authoritative pedagogical methods, with the teacher in power interpreting texts selected by the central state government. Only the few would advance to the upper secondary school: in 1950 only $5 \%$ would do that in Denmark (Larsen 2013). With the analogue electronic media (and the pro-democratic ambitions after the second world war), the authority of the teacher was diminished because of the new information situation brought about especially by television (Meyrowitz $1985)^{2}$. Now the students knew almost everything which before had been secret, because they did not need to be able to get their hands on and read difficult books; however, to be educated and acquire Bildung, they still had to be able to read and write (ibid). Also, now the teacher could select more texts because of the copying machine. The pedagogy was changed; now there was more dialogue and a more equal relationship between the students and the teachers. The praxis of Bildung was brought much closer to the idea of Bildung. According to Luhmann (2006: 212), the contingency formula of Bildung in the twentieth century was 
adjusted to the loss of canon-based certainty. This is the form of life-long learning, and the reflexive formula now is 'learning to learn'. The idea goes back to Humboldt: "The young man (...) is engaged in a double manner, first with the learning itself, and then with learning to learn" (here quoted from Luhmann 2006: 213). According to Luhmann, "Now you have to choose teaching material (there are already too much of it), and an opportunity is - instead of its "inner" value - to ask about the chance it provides to practice how to learn and prepare themselves for a future where you constantly have to learn new things" (Luhmann 2006: 213).

\section{The Problem}

Today, all parts, sectors and levels are altering and changing in accordance with new digital communication media. Not least the production forms are changing from the form developed in the epoch of industrialisation, in which there was a sharp distinction between production, distribution and consummation. Now, we see a contraction called produsage (Bruns 2008). We also see new forms of networking, intercreativity (ibid), dissemination of content and forms of convergence and participation cultures characterised by shaping, sharing, reframing, remixing and appropriation (Jenkins 2013, 2008, 2006). We are living in a new society, or in a society which is on its way to becoming a next society (Baecker 2007).

In his book No Sense of Place, Meyrowitz (1985) shows how analogue media changed the spatial conditions for socially mixed situations, which before were differentiated, creating new information situations. Now people could hear and see what was happening in different places without entering these locations. Now, with digital media, we can do more that see and listen - we can also intervene; we can do things in places where we are not physically seen.

For centuries, the school has functioned as a social system processed in a closed room: "The interaction takes place in enclosed spaces that are not public, so that the distraction from the outside world can be minimized" (Luhmann 2006: 131). For centuries, the four walls have protected what was going on in class: "Especially ensures the spacious inaccessibility of teaching [from outside] that the education system can control its own theme and determine the beginning on, alternating or abandonment of the themes (which obviously does not in itself lead to concentration of attention)." (Luhmann 2006: 132). With analogue electronic media, many things changed in education because of the new information situations (Meyrowitz 1985, Tække \& Paulsen 2013a). But with the digital media, not only the information situations change again, but also the interaction situations (ibid). Because of the new information situation, the students can keep updated, for instance through search engines, so they will always be able to check facts, also in regard to what the teacher says. In regard to the new interaction situation, students can interact with each other during the lessons without audibly disturbing. Also, they can draw on their networks, for instance, their parents or siblings, or ask questions in Facebook groups or through specialised hashtags on Twitter. We have observed that classrooms have opened up, meaning that the students can now access content, conversations, computer games, friends, etc. from all over the world (through the Internet). The schools themselves invest huge sums of money in equipment like wireless networks and digital blackboards. Yet, the teachers have difficulties using the new media for educational purposes and tend to either prohibit or ignore the use of digital media (Tække \& Paulsen 2013a). Both strategies - prohibition and ignorance - generally fail for several reasons, but first of all because the new problem of Internetrelated distractions in the class room stems from a lack of norm-building aimed at the new situation provided by the new communication space of digital media (ibid., Meyrowitz 1985). At the same time, the new possibilities for teaching provided are not actualised or invented. 
On the whole, this means that we see a Bildung of students that belongs to yesterday's media environment - Bildung in which students are treated as if we were still living in the epoch of industrialisation, and communicatively speaking before digital media. Framing the two presented main ideas of Bildung: how do we educate students to have the ability to think freely and for themselves within new society? And how do we provide a Bildung by which students can co-create a better future in this new media environment? Perhaps this new media environment is the very requirement for providing such a Bildung!

But what we see as a 'first moment' of the educational response to the new situation is the beforementioned prohibition/ ignorance strategy, possibly combined with a narrow-minded focus on competences, like how to use this or that application, which does not provide anybody with Bildung, even though basic competences are a requirement for participating in a higher social level of taxonomy.

\section{Biesta's Contemporary Ideas of Bildung}

Drawing on Heidegger, Levinas, Foucault and others Biesta (2006: 6) claims that the humanism and tradition of Bildung have failed, in the respect that we cannot (and should not) pinpoint the essence of man. Therefore, education cannot entail placing individuals in an already fixed order; education involves a responsibility for each individual's possibility to unfold, in a unique way, what it means to be a (good) human being in the world today. The role of the teacher must be understood as the responsibility for unique individuals' "coming into the world" and a responsibility for the world as a world of plurality and difference (Biesta 2006: 10). The main educational question for Biesta is how we can live together with others different from ourselves in peace and relationship (Biesta 2006: 15). Biesta finds a major shift from education to learning, having redefined education to only support and facilitate learning. This change provides a business-like pattern in which students are seen as customers who must get "value for money". This is problematic because customers in principal know their needs, which is not the case for the 'newcomers' we take the responsibility to educate (Biesta 2006: 21). Another problem with the logic of learning is that it makes it very difficult to raise questions about the content and purpose of education. When the content is only observed from the viewpoint of the consumer or the market, we face problems with the pedagogical knowledge and the democratic aim (Biesta 2006: 24). According to Biesta, these are the main problems in relation to Bildung: the lack of human essence, the learning discourse and especially the plurality question. Biesta's answer is that pedagogy must imply openness: "an openness toward new and different ways of being human" (Biesta 2006: 106). The problems and challenges of today call for education to focus on the becoming of unique individuals (in modes compatible with everybody else also acting in unique ways, forming a shared space of plurality). The strategy to achieve this is a paradoxical deconstructive combination of education and its undoing. The goal for the teacher is the moment when the students find their own unique responsive and responsible voice. The teacher's responsibility is therefore a responsibility for something unknown (Biesta 20o6: 116). To teach democracy, schools have to be democratic (Biesta 2006: 124). Through the works of Hanna Arendt, Biesta (2006: 133) comes to a concept of action, which is only possible in a lifeworld where others are also able to act. To become subjects, we are in need of others who can respond to our beginnings: "If I would begin something, but no one would respond, nothing would follow from my initiative, and, as a result, my beginnings would not come into the world and I would not be a subject" (Biesta 2006: 133). The (positive) problem is that others (re)act in unpredictable ways, because we always act in relation to others who can act themselves ${ }^{3}$. This is the impossibility of staying in control of one's own actions, which at the same time is the condition for one's beginnings becoming something in the world (Biesta 2006: 133). If we try to control the responses of others or deprive others of the 
opportunity to begin, we cannot come into the world together as subjects, hence subjectivity is not a possibility (Biesta 2006: 135). On this background, in order to make democratic subjectivity possible in schools, we must create an educational environment in which students have a real opportunity to begin taking initiative (Biesta 2006: 138).

\section{Analysis: Bildung and the New Media Society}

Digital competences are very important. However, competences are not enough. Students need Bildung in relation to the social, which has now become enriched and much more complex due to the endless number of new possibilities for formation. The problem is that nobody knows what Bildung means in the new media environment. In the following, we will put forward a synthesis of the above presented theory on Bildung and the theory of the three waves, which we have developed in the Socio Media Education Experiment, mentioned in the introduction (see Tække \& Paulsen 2012a, 2012b, 2013a 2013b, 2014, 2015b, 2015a, 2016a, 2016b). This means that we now put forward three empirically supported and theoretically enlightened aspects of Bildung, which together form the first outline of Digital Bildung. First, we briefly present the theory of the three waves.

\subsection{SME Experiment and the Theory of the Three Waves}

Let us first sketch out our theory about how class teaching seems to change in the new media environment (Tække \& Paulsen 2015a, 2016a, 2016b). The theory is based on empirical findings from a three-year action research project, the SME experiment from 2011-2014 (Tække \& Paulsen 2012a, 2012b, 2013a 2013b, 2014, 2015a, 2015b, 2016a, 2016b). The research question was: what consequences do digital media and wireless networks have for classroom-based teaching? Our thesis was that the old school system reacts to the new conditions for teaching and learning shaped by the digital media. We proposed that what is happening is a deconstruction of the old closed classroom in favour of an open community between students, teachers and third parties. However, the deconstruction does not happen at once. Rather, we suggest that it arises in three waves (Tække \& Paulsen 2015a, 2015b, 2016a, 2016b). In the first wave, the old classroom is opened up. Students are distracted and teachers do not know what to do. The Internet becomes a challenge to teaching in this phase. In the second wave, attention is drawn back to the educational interaction between teachers and students through the use of social media. In this phase, social media are used to re-stabilise the teaching situation and intensify it. In the third wave, teachers and students go a step further, succeeding in establishing educationally relevant interaction with third parties (authors, researchers, foreigners, etc.) through the Internet. Only in this final phase does the Internet become a means to enable new perspectives that thoroughly alter the old educational setting. In the following, we are going to give examples from the third wave to discuss Bildung in the media environment of today and tomorrow.

\subsection{A Product of Education and Free Thinking}

If we look at the time before teachers began experimenting with the third wave (educationally relevant contact in and out of the classroom), one of the most important elements in the SME experiment was the work with reflexivity (here: attention to attention). The teachers had to help students develop a reflected use of media, and they themselves also had to develop a reflected and understanding way of addressing the students' use of media. This included helping the students to be attentive in relation to their attention. In all probability, this double task can only be carried out adequately through the interaction between the students and the teacher. Neither the students nor the teacher have a priori knowledge about the right way to handle this new complexity. The communicatively achieved attention to attention (and the problems related to attention in the new media environment) can be seen as a way of reducing and controlling the new complexity arising 
from the infinite possibilities of interaction in (and out of) the classroom. One guiding principle here is that it is not possible to multitask (König 2005, Lee et al. 2012, O’Brien 2011, Pashler 1994, Tække \& Paulsen 2013). Naturally, if one of two activities is automated, like when you are driving a car while chatting, it is possible, but if the traffic situation turns complex you need to stop talking. Taking social media as an example, a student can see that there is an update on Facebook while listening to the teacher, learning something new, but not read or write an update while still following the new argument the teacher puts forward. On the other hand, one has an ability to switch between different activities, depending on how good one's short-term memory is and how strong one's determination and situational involvement is in the learning activity. Also, reading, writing and IT skills have a strong effect on how good the single student is at switching back and forth between the teaching interaction and other interactions and doings, like gaming, surfing on the net, reading news or other such things. The single student must know their own attention scope, skills and shortcomings, and the teacher must help them understand and take action on the basis of a reflected point of view. Students' level in the different school subjects also has an influence on how much averted attention they can afford. This means that it can be different, not only from student to student, but also from English to maths, what the student can afford in terms of averted attention (Tække \& Paulsen 2012b). The work with attention and self-reflection in the first year of the SME experiment was an important step for the students on their journey towards the capacity to think for themselves and develop social responsibility. Together with educational interaction using the social media of Twitter, it provided them with the skills needed for their later contact in and out of the class. But here we are mostly at the competence level: competences helping the student not to try to multitask, competences to use, for instance, Twitter for educational interaction. Thus, it is mainly through the shift to third-wave education that the student learns to make informed decisions - to think for themselves - in a proper sense of Bildung. This happens when it is not the teacher who tells the student what the text is about or what the meaning of it is, or how to write a text or sell a product. Instead, it is "real practitioners from the surrounding world" who present their texts, methods, experiences and meanings. The teacher becomes a guide who helps make the connections, provide relevant material to prepare the meeting and stimulate reflection on how the student has performed in the meetings. Over time, the students learn how to interact within the new media environment and take responsibility for the whole arrangement and the situation and its organisation. They learn to think for themselves and make decisions in new social situations in a professional context. In the third wave, it is new and real situations that motivate and provide the students with Bildung (Bildung in a sense that matches contemporary media society), rather than the surrogate learning situations developed under the former media societies. This means that the students and their teachers are not only performing language games with almost no other consequences than the influences and reactions from each other. In the third wave, the students are in real situations with real consequences, including real persons having a situation - a meaning or profession the students must try to understand and relate to.

In The SME-experiment there were, for instance, two cases in which other school classes were contacted - one in Denmark and one in Germany. In both cases, the students were very engaged and motivated by communicating with others outside the class, here with other students of the same age (Tække \& Paulsen 2015b, 2016a, 2016b). According to the teachers, more students were drawn into the schoolwork than usual. It felt more important to the students to contribute, and also the quality was higher than normal because of a feeling of being observed by others of the same age, and because of a feeling of representing their own class. The students had to perform in a meeting with strangers, in a situation, which - because of the arrangement - forced them to make decisions on the spot, to think and at the same time do so within an educational framework. In relation to both 
classes, they also acquired new perspectives and information transcending the information given by their own teacher. In communicating with the German class, it also became important to write correctly, and the students felt that the language written by the German students was a more 'real' German than that in the books and spoken by the teacher.

Student: I feel that I learn better by communicating instead of reading a book. Not only the grammar, but also the language as such. If you communicate with someone from Germany, you learn better German than if you sit in the class talking German. That's the way it is.

Student interview 13 14/3 2013

As seen in the quote, the student comes to the conclusion that she learned more from such a meeting than from the old-fashioned way of educational organisation. Moreover, the students also felt that they themselves had something to contribute with in relation to the other classes, which also pinpoints a growing self-confidence and self-awareness (Tække \& Paulsen 2015b).

Looking at the problem from the perspective of the paradox, we neither opt for education in terms of discipline, humility and obedience, nor a kind of laissez-faire education. We observe the problem in a way that education and teachers must help students become self-assured in the new media environment. Education must provide students with the ability to think and be capable of participate in the social in contemporary media society. Bildung in contemporary media society means that students can understand, participate in, alter and transcend the new social situations enabled by the digital media.

\subsection{The Old Curriculum in a New and Interactive Way}

In the third wave, students work within a new framework and in a new way, enabling them to interact, for instance, with an author or with students from other schools. Because of the introduction to, and encounter with, others from the surrounding society, the students experience educationally relevant topics through the way they are interpreted by others than their own teacher. Before, the educational interaction was performed in what we have defined as an 'echo room' - a room where interpretations were not radically challenged by other interpreters than the teacher, the textbook and the students, i.e. the closed classroom community (Tække \& Paulsen 2014, 2016a). In the third wave, the interaction with others outside class provides synchronisation with how things happen and are performed outside school. Curriculum is actualised and becomes more relevant and motivating for the students (Tække \& Paulsen 2015a, 2016a, 2016b). In the old days, the curriculum consisted in learning classical texts in Latin and ancient Greek, and later on translated ancient texts. Also maths and foreign languages, world and national history and literature were among the subjects that someone with Bildung had to be educated in. After the introduction of analogue electronic media, especially television, and the youth revolt in the late 1960s, many contemporary topics became part of curriculum. Simultaneously, more equal relationships developed between teachers and students, along with group work and project-oriented teaching. But even when, for instance, films and articles from newspapers were used, the teaching materials were selected and presented by the teacher and interpreted within their framework. The texts were mostly old books that mediated, for instance, poems and descriptions of authors, or copies often taken from old books. Altogether, this meant that education and its social forms and knowledge were developed in accordance with the media matrix of that time. Not that there was any consensus between different schools, but the tendency is clear enough. Luhmann points out that in this society, the curriculum way of Bildung changed to the form of learning to learn, because the complexity had increased beyond the level where it was possible to figure out what knowledge would help students manage after having 
completed their education. All this also holds true today, but with an even higher level of complexity, brought about by the overload of available information through the Internet. Looking at the problem from the perspective of the 'Bildung paradox', it is neither advisable to select pure classical curriculum nor pure learning to learn, but both at the same time. In addition, we propose a new form of pedagogy in which digital media is used to find, observe, interact with, store and retrieve teaching content.

From the second year in the SME class, the teachers had to work on cultivating the contact between the class and its surrounding world to establish dialogue with network resources. The partly restabilised educational community of the class was in this way supposed to transform the otherwise disturbing contact with the surrounding world into a driving force, hereby improving the situation so that the contact, instead of drawing away attention from the educational interaction, would intensify it. Moreover, our thesis was that this contact would enrich and inspire the information situation with angles and perspectives going beyond what the teacher could offer. Generally seen, this move would enhance the class competences by working in a mode adequate to the digital era.

One example is that the literature teacher initiated contact to the Danish poet Kasper Anthoni. The class read one of his collections of poems and through two sessions asked him questions on Twitter. According to the teacher, the students usually have no or only little interest in poetry, but this contact really got them interested. Also, according to the students the experience was motivating and mind-blowing.

Student 1: I think it was a totally different way to analyse poems. A much better way I think.

Student 2: Yes, when we have the author [on Twitter] we can ask him questions if there is something we cannot understand in the poem and ask him what he meant, and then he can post a tweet about it.

Group interview1 31/10 2012

Student 1: It helps with the interpretation. If I ask him how he got the idea, then he relates that he had a feeling, and then it is easier to interpret the poem. I think it was good.

Group interview 531/10 2012

The interaction with the poet is exemplary of the concept of the third wave, where the class definitively succeeds in drawing in resources from outside class and performing new and adequate educational forms. The teacher becomes less of a focus but still takes responsibility, allowing the students to get to the resources, which become the new centre of their attention and reflection. The teacher set up the connection to, and appointment with, the poet and helped the students read the book, formulate good questions and organise groups for the sessions. These efforts are good investments because of the students' motivation and engagement triggered by the direct contact with a real author through Twitter.

It would be possible to do the same with classical literature; thus, a contemporary author or literature researcher could take on the role and interact with the students - or it could even be taken on by students from other schools, as mentioned in the above section. Even before electronic media, new texts were taken up and became part of the curriculum, but this tendency has increased over the period of electronic media and is still evident in the contemporary media environment. Maybe therefore, in Denmark we are witnessing a revival of different educational canons driven forth by 
politicians. This is not a disaster, since it provides us with history, as long as we also have new texts and as long the teaching method is up to date. In other subjects, like business, the teacher gave the SME class assignments that involved local companies, using predefined types of media that the teacher knew the companies used, such as Twitter and Facebook. This gave a very positive result in regard to motivation, engagement and the information situation. The students, some of them not usually motivated, explained in interviews that it was relevant and authentic to communicate with local businessmen and that it helped them applying theory to their cases. In this example, the theory was not new, but the students found it meaningful to work with because of the application to real businesses. Our conclusion is that it is possible to use such interactive methods with great success: the students learn what is intended, the curriculum, but in a way that motivates them, and at the same time this way provides them with the learning and working methods of today - of the present media environment. Also, they learn unexpected things and, more importantly and at a profounder level, become educated by the teacher-mediated contact with others from the surrounding world. This is Bildung in a double sense, since both methodology and content come into play; the same applies to the teacher and the world of plurality.

\subsection{Meeting up with the Others}

In the third wave, students are confronted with others: either other students, professionals working within the fields relevant to the topics they are studying, or exponents of the kind of people the teaching is about. Also, there is a social aspect because these meetings often take place in the context of groups and networks. What Biesta asks for is exactly what is brought about by the new pedagogy of the third wave: students meet with a plurality of others. The perspective is vast; it will be possible for students to meet all kinds of people who before they could only read about. It would, for instance, be possible to meet with refugees, real refugees in real situations, when working with the topic in social studies. Students will not only get a description, but also meet a real human being and, through the interaction, experience other people's unpredictable ways of reacting. The teacher thereby fulfils the responsibility for unique individuals' 'coming into the world', which happens here when the students meet others. By doing so, the teacher helps the students on their way to becoming able to contact other people, take initiative, listen to other people's points of view, react, ask questions, reflect and do things together with others. Maybe the students do not know that meeting other students from other countries, a pregnant woman or a refugee will endow them with the needed Bildung. The teacher must let these meetings happen with an unprejudiced attitude, which makes the students open to difference (Tække \& Paulsen 2016c). In this setup, students (ideally speaking) find their own unique responsive and responsible voice and, through dialogue with others, learn not only to respect, but to relate to, understand and take the attitude of real, different others. The students will try, over and over again, to begin a conversation and experience that nothing follows from such initiatives, if it were not for the responses from others. They will experience that others answer in unpredictable ways, and get used to taking part in, and responsibility for, this type of communication. According to Biesta, this will eventually mature the students and transform them into subjects, taking them from infantile ways of reacting to grown-up ways of reacting to others and otherness (Biesta 2016). From a Luhmannian point of view, they will have the chance to build up internal complexity that will help them reduce the complexity of doubly contingent social situations. In turn, this means that the third-wave pedagogy is providing the students with a form of Bildung that prepares them to take part in contemporary society.

\subsection{Why Digital Bildung?}


The network culture of the Internet, just like the transparency of the television, now penetrates all of society. The forms developed for observing, networking, producing, etc. are now expected everywhere and very often, almost always, underpinned and made possible directly by digital media.

A well-known difference between mass media and digital media is that mass media tends to present topics or persons seen from different angles, while digital media, or our use of digital media, tends to give us what we expect, want and like. At least in public service television, an object must be discussed from a variety of angles to provide the viewer with an objective knowledge about it, i.e. that different positions construct the object differently. The school system must cultivate the students in relation to the bias of digital media (and also different kinds of propaganda in mass media), where we tend to end up in what has been called filter bubbles and echo rooms, indicating that objects are only observed from one angle. However, with digital media, the education system can go a step further and let the students meet directly with persons who are presenting their own real otherness. The teacher in this situation must act as a catalyst for the students forming their opinion, providing them with information, theories, perspectives, etc. that can help them understand, on the one hand, the real otherness of a given person and, on the other hand, also let the students meet with other positions. This means that education and teachers have a responsibility to provide students with a Bildung that animates them to do what is impossible in mass media: meet directly with the persons they are forming their meanings about. Refugees, for instance: are they antagonists, protagonists, or what are they? Moreover, education and teachers must provide students with a form of Bildung that animates them to feel responsibility for investigating topics from more than one angle and provides them with knowledge and competences that enable them to do so.

Meeting with others was the essential idea of the third-wave experiments of the SME project. By way of a different example, let us look at another (also mentioned in Tække \& Paulsen 2015a) case in which some of the students and teachers from the SME class watched a TV documentary at home about the financial crisis, using Twitter to communicate about it. After some time, one of the students observed that the rest of the Danes watching the documentary while on Twitter used a global hashtag to communicate about it.

Researcher: So you were discussing the documentary with the others from the class and then it was extended. What do you think of that?

Student: You also got other people's opinion [...] and there were really many opinions and tweets and it was going on long after the program ended. It was really exciting.

Researcher: Was it good for the discussion that it was not just the class and your teachers?

Student: Yes, I believe so. Because we maybe have a little bit the same opinion in class, because we have the same teacher and we do the same things. And then there were other people's opinions, people that are in a different place in their life and have a different perspective on society.

Student interview 9 9/1-2013

An educationally relevant hole is made in the echo room of the class, and perspectives arrive from the outside, representing an otherness. The typical situation in the echo room, where the teacher decides what is good and bad, true and false, fades away. As we saw in the case of the poet, the cultivated opening undermines this position, and the teacher must assume a new role. Not necessary a weakened one, but more adequate to the new media environment - as a moderator, organiser and Builder (i.e. 
Bildung-shaper) helping the students understand the different opinions in society. We asked the student what it would be like if the SME class had not had the contact to the external world:

Student: Well, then I believe it would be biased; the teacher's opinion would shine very much through. Now we get others' opinions, others' view on the things. This means that what the teacher says is not just the right thing, but that you can also find information about: can this really be true? Why does she say that? And such things. So it makes us think in another way.

Student interview 9 9/1-2013

This opening is archetypical for the third-wave education method and shows how other persons with other perspectives provide the students and teachers with points of view from the real world of society. Now, resources from the outside are actually there, and it would have been possible for the students not only to take account of the views of others, but also to interact with them, and in this way have investigated further what the opinions consisted in, who the others were, etc.

The paradox that Biesta provides us with is that becoming a unique individual entails a paradoxical deconstructive combination of education and its undoing. The responsibility of the teacher becomes a responsibility for something unknown, meaning that the teacher cannot enter the classroom with a fixed idea of what the students must learn in a substantial sense, but only with the idea that a certain topic, issue or arrangement forms the basis for the work. In our framework, this means that the teacher becomes the mediator who not only represents difference and otherness through old books and their own knowledge about otherness. The responsibility becomes actually allowing the students to meet the otherness, meet the actual otherness presented by real persons, real human beings.

\section{Concluding Remarks}

Our conclusion is that the ideas and cultivation of enlightenment, and thus Bildung and humanity, must find new forms in the contemporary media environment. From our point in history, it seems that now more radically than ever before, we have the possibility to get really close to the concept of Bildung developed in the time of enlightenment. Seen through one of the paradoxes of Bildung, we now see a possible way to educate students to become independently thinking beings, to become selfassured, and at the same time develop a responsible and experienced eye for real otherness. Through the introduction of analogue electronic media, especially television in the "democratic post-warperiod", more equal relationships between teachers and students and the beginning of group and project work developed. In this period, we also saw examples of different kinds of visitors in classes as exponents of otherness, and classes going on trips into surrounding society to meet otherness. But now, in a situation characterised by digital media, the meeting with third-party persons can be a logical part of everyday education. This is logical because in the new media environment everybody (at least in the first world) has access to digital media and resource persons, and networks are therefore only a click away. Both teachers and students are becoming familiar with this mode of the contemporary communication environment from their private life and also from their interaction with the officially community, with municipalities, through shopping and from what they see on television and in movies, etc. In the same way that people in yesterday's society would have written a letter to ask a person for something, or borrowed a book to learn about something, it has now become logical to write an e-mail or a tweet to ask questions, and to search the web for knowledge. Time and space have been altered in regard to communication; we now expect here-and-now communication with people living at a distance from us, and this logic entails both possibilities and risks. In this paper, we have written only a little about the risk of distraction, but we can also mention the risk of finding bad resources or dangerous persons. Obviously, it is necessary to provide students with a Bildung that can 
match both the risks and possibilities of digital media. We suggest a digital Bildung that forms the students to reflect on their attention, choose the right medium for their tasks, etc. in teacher-guided sessions with real people representing real otherness in all relevant areas.

\section{References}

Baecker, D. (2007). Communication with computers, or How Next Society calls for an understanding of temporal form. Soziale Systeme: Zeitschrift fuer soziologische Theorie, Vol. 13, pp.409-420.

Biesta J. J. Gert, (2006). Beyond Learning. Colorado: Paradigm Publishers.

Biesta J. J. Gert, (2016) The Rediscovery of Teaching: On robot vacuum cleaners, non-egological education and the limits of the hermeneutical world view, Educational Philosophy and Theory, 48:4, 374-392, DOI: 10.1080/00131857.2015.1041442.

Eisenstein, E. (1983). The Printing Revolution in early Modern Europe. Cambridge: Cambridge Uni. Press.

Bruns, A. (2008). Blogs, Wikipedia, Second Life and Beyond: From Production to Produsage. New York: Peter Lang.

Jenkins, H., Ford, S. and Green, J. (2013). Spreadable media - Creating value and meaning in a networked culture. New York: New York Uni. Press.

Jenkins, H. (2008). Convergence culture: Where old and new media collide. New York: New York University Press.

Jenkins, H. et. al (2006) Confronting the Challenges of Participatory Culture: Media Education for the 21st Century. London: The MIT Press

Kant, E. (1803). On Education (über Pädagogik): http://oll.libertyfund.org/titles/356

Klafki, W. (2014[2001]). Dannelsesteori og didaktik - nye studier. Aarhus: Forlaget Klim

König, C. J. (2005). Working Memory, Fluid Intelligence, and Attention Are Predictors of Multitasking Performance, but Polychronicity and Extraversion Are not, in HUMAN PERFORMANCE, 18(3), pp 243-266.

Larsen, S. N. (2013). Dannelse - en samtidskritisk og idéhistorisk revitalisering. København: Fjordager.

Lee ,J., Lin, L. \& Robertson, T. (2012). The impact of media multitasking on Learning, in Learning, Media and Technology. Vol. 37, No. 1, March 2012, pp. 94-104.

Luhmann, N. (2006[2002]). Samfundets uddannelsessystem. København: Hans Reitzels Forlag.

Luhmann, N. (1995[1984]). Social Systems. California: Stanford University Press.

Meyrowitz, J. (1985). No Sense of Place: The Impact of Electronic Media on Social Behavior. New York: Oxford Uni. Press. 
O’Brien, Jennifer (2011). UCSF Study on Multitasking Reveals Switching Glitch in Aging Brain. www.ucsf.edu

Pashler, H. (1994). Dual-task interference in simple tasks: data and theory. In Psychological Bulletin, $16,220-244$.

Tække \& Paulsen. (2016a). Undervisningsfcellesskab og læeringsnetværk i det digitale samfund. København: Forlaget Unge Pædagoger.

Tække \& Paulsen. (2016b). Digitalisation of education - The three waves. Paper accepted to the Nordic Sociological Association: Knowledge-Making Practices and Sociology's Global Challenge 11-13 August 2016, Helsinki, Finland.

Tække \& Paulsen, (2016c). Steering of Educational Processes in a Digital Medium Environment. in Journal of Sociocybernetics, Vol. 13, Nr. 2, 2016, s. 72-83. Direkte link: https://papiro.unizar.es/ojs/index.php/rc51-jos/article/view/1175/1054

Tække \& Paulsen, (2015a). The three waves of the Internet - From closed to open classrooms - the evolution of educational communities within the digital medium environment. Paper for the NordMedia 2015 conference: Media Presence - Mobile Modernities University of Copenhagen 13 - 15 August. Division 5 Media Literacy and Media Education. http://pure.au.dk/portal/files/89313758/NordMedia_2015_Paulsen_T_kke.pdf

Tække \& Paulsen. (2015b). Digital dannelse på HF og VUC - Udfordringer, erfaringer og perspektiver. København: Unge Pædagoger.

Tække \& Paulsen. (2014). Hybridisation of Education : leaving the Echo room. Paper presented at Hybrids - Observed with Social Systems Theory, Dubrovnik, Kroatien.:

http://pure.au.dk/portal/files/7483046o/Hybridisation_of_Education_Taekke_og_Paulsen_

Tække \& Paulsen. (2013a). Sociale medier i gymnasiet - mellem forbud og ligegyldighed. København: Forlaget Unge Pædagoger.

Tække \& Paulsen. (2013b). Social Media and Teaching - Education in the new media environment. Paper to the 4oth anniversary Nordmedia conference: Defending democracy. Oslo and Akershus University College, 8-11 August 2013. http://pure.au.dk/portal/files/54508198/Social_Media_and_Teaching._Taekke_and_

Tække \& Paulsen. (2013c). Social Media and the Hybridization of Education. in Cybernetics \& Human Knowing, Vol. 20, Nr. 1-2, 2013, s. 141-158.

Tække \& Paulsen. (2012a). The challenge of social media - between prohibition and indifference in the classroom. Conference Paper for the Thirteenth Annual Convention of the Media Ecology Association: The Crossroads of the Word. 710 June 2012 Manhattan College Riverdale, New York: http://pure.au.dk/portal/files/45108803/MEA_2012_Taekke.pdf 
Tække \& Paulsen. (2012b). Attention to Attention - Reflexions on new Media in Education. Paper to The Danish Conference of Sociology: Troubled Identities. 19 - 20 January 2012. Aarhus University. Working group: self-referential systems and network communication. http://pure.au.dk/portal/files/43983449/Attention_to_attention.pdf

\footnotetext{
${ }^{1}$ In the December 1784 publication of the Berlinische Monatsschrift (Berlin Monthly), edited by Friedrich Gedike and Johann Erich Biester, Kant replied to the question posed a year earlier, see: http://www.artoftheory.com/what-isenlightenment_immanuel-kant/.

${ }^{2}$ Before television, knowledge was bound to specific places and/or texts, for instance the facial expressions of a speaker, what men do when there are no women with them, that teachers do not know everything and sometimes (back when TV was new) would physically punish pupils, etc.

${ }^{3}$ Here, Biesta comes close to Luhmann's (1995) theory of communication and the concept of double contingency, which is the basic and necessary situation of mutual uncertainty, from which communication takes off and is made possible.
} 